\title{
What is Freshness?
}

\author{
Peter Mansfield* \\ Independent Doctor and Health Scientist, UK
}

Submission: December 16, 2017; Published: March 12, 2018

*Corresponding author: Peter Mansfield, Independent Doctor and Health Scientist, Newark-on-Trent, UK; Tel: +447957861775;

Email: mansfield.pj@gmail.com

\section{Summary}

All nutritional advisors recommend that an ample portion of fresh food be eaten regularly. Many can define it, but very few understand what it achieves. Underlying principles, that are yet to be scientifically acknowledged, are the subject of this paper.

\section{Biochemistry}

We can be proud of the accomplishments of biochemistry, particularly during the past century. We now know the structure of most of the substances that occur in living things, and a great deal about how they interact metabolically. However, these substances and their interactions are manifold and very complex; so far we know less about how order and grace are created and maintained in the structures and functions of living organisms. A major part of the reason for this deficiency is that we know almost nothing about how organisms arrange their substances into tissues, so fashioning, developing and maintaining their forms.

Genes get the credit for this, and certainly do explain how one generation of organisms reproduces another, and how ageing proteins within each organism are replaced with faithful replicas, day by day. But none of that gets us nearer understanding the organisation and maintenance of each organism's form in the first place - let alone metamorphosis, in species that exhibit it. This is particularly puzzling when we realise how large a fraction of the genome is shared between creatures with hugely differing bodily forms and habits. Even within a single organism, we cannot account genetically for the differences between the structures of different cell lines and organs, when the genome is basically identical in all the cells of that organism. We can propose genetic switches, but all these too would be the same in every cell. Chemical gradients and electromagnetic fields are plausible reasons for simple intercellular differences, but we struggle in vain to see how they can ever be complex enough - let alone discontinuous enough - to account for the specialised tissues, organs and systems visible to histologists, anatomists and taxonomists. As the wisest biochemists freely admit, form is beyond the scope of biochemistry.

\section{Agronomy}

Farming and horticulture have also developed massively over the past hundred years, devising novel crops and methods of animal husbandry; ever intensifying both inputs and yields. Agronomists and physicians lead closely parallel lives.

Besides their dependence on modern agronomy, however, farmers and gardeners still have enormous regard for the way things grow. For most of them, this is set in the wider context of a deep love and reverence for nature writ large - in a word, for life itself. They observe how neighbouring plants take account of each other; how each draws moisture and minerals from the soil, and gradually unfolds through simple to more complex forms, arriving at length at the mature crop they harvest.

Most growers will testify to the delightful flavour of a fruit or vegetable, picked fresh and eaten there and then. It explodes in the mouth. Milk straight from the cow or goat is sweet and rounded in flavour, qualities dulled by pasteurisation and storage.

But this is the stuff of cookery books and gastronomy, little of which betrays any debt to chemistry. Unlike physicians, chefs-de-cuisine has nothing professional in common with agronomists.

Biochemists have occasionally puzzled about this. Albert Szent-Gyorgyi is probably the most famous example. Having isolated vitamin $\mathrm{C}$, he noted how much less potent it was weight-for-weight than in the tissue from which he isolated it. He stressed to his students, how differently chemistry proceeded in the context of a live tissue than between purified reagents in vitro. One of them went on to manufacturer nutritional supplements by growth rather than chemical synthesis, and to demonstrate their greater effectiveness as nutrients compared with their purified equivalents. Happily, this habit is spreading.

The allusion from this is that in agronomy, too, there is a gulf between the formal chemistry we understand, and the growth processes in nature which we do not yet comprehend. 


\section{Growth}

We can, however, observe the difference imparted by the growth, say, of a lettuce or a cabbage. From germination to maturity, the seed unfolds through a succession of forms, fed by soil and air, and energised by sunlight. Each layer of leaves is displaced outwards to make place for fresh axial shoots. The leaves green progressively as they enlarge and ripen. But a cabbage takes much longer to ripen than a lettuce, and in the process acquires a more complex structure, more intense colour and far stronger flavour. So we can observe at least two properties that growth contributes to a plant. One is vitality, a measure of the dynamism of its growth in any moment. The other is structure, an accumulative property achieved over time through repeated cycles of this dynamic growth. Yet, if analysed chemically, the plant can still be reduced to small dead piles of purified ingredients, and water. Which tastes better, and why?

Here I submit speculations of my own, though they have some basis in Kirlian photography and circular chromatography of fresh living specimens.

Vitality is far more intense in plants grown in clean, healthy soil without recourse to chemical fertiliser or biocides. It explains the more intense flavour people report, and justifies the distinction of organic from chemical agriculture. More intense vitality, in turn, creates more robust and detailed structure in the tissue of the plant, enhances its immunity to attack and therefore its structural integrity.

Cooking plants releases their vitality in a matter of hours; hence the rather dull flavour of a baked potato, after overnight storage. Out of the oven, a similar potato tastes more gratifying because the vitality is radiating away from its

This work is licensed under Creative

Commons Attribution 4.0 License

DOI: 10.19080/NFSIJ.2018.06.555676 tissue, to be intercepted by the taste organs of the consumer. (Cooking also bursts indigestible cellulose, breaking cell walls and making cytoplasm available to taste and digest. This offers an alternative explanation of the flavour just after cooking, but does not account for the loss of flavour in storage).

Vitality, in this sense, is an important nutrient. It can be eaten, and enhances the vitality, structure and immunity of the consumer - just as of the food it came from. This not only deters invasive micro-organisms but diminishes the risks that the structure of the body will decay or stray - which lead to ageing and cancer.

Freshness is synonymous with vitality. Raw food may possess vitality, but may have lost it gradually in storage or rapidly in cooking, refining or attack by fungi. Tubers, seeds, nuts, corms and bulbs, formed in nature to be dormant between seasons, are live and therefore fresh despite storage. Their vitality may be released by cooking, chewing or sprouting into fresh shoots.

I have not, in this brief essay, dealt with foods from animal sources. The same principles apply in a far more complex way.

\section{Conclusion}

Freshness is a necessary but insufficient property of the diet. It is vitality that coveys the benefit. This is ensured in any plant food item by harvesting without physical damage or fungal decay, then eating fresh or very shortly after cooking. Crops that will grow in the next season retain their vitality despite prolonged winter storage. Consuming vitality every day is vital (sic) to general immunity, and the key to preventing or diminishing all illness - in particular slowly progressive "consumptions" such as tuberculosis, leprosy ageing and cancer.

\section{Your next submission with Juniper Publishers} will reach you the below assets

- Quality Editorial service

- Swift Peer Review

- Reprints availability

- E-prints Service

- Manuscript Podcast for convenient understanding

- Global attainment for your research

- Manuscript accessibility in different formats

( Pdf, E-pub, Full Text, Audio)

- Unceasing customer service

Track the below URL for one-step submission https://juniperpublishers.com/online-submission.php 